Michael Eder

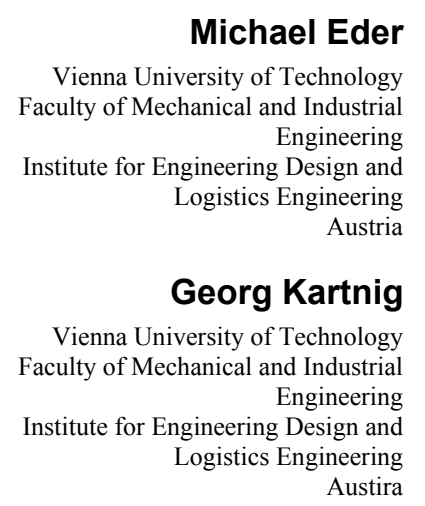
Vienna University of Technology Engineering
stria

\section{Calculation Method to Determine the Throughput and the Energy Consumption of S/R Shuttle Systems}

Shuttle systems are used in high performance automated storage/retrieval unit load systems. Each storage level is serviced by one shuttle. On the front side of the rack there is a lift for storage and retrieval. A different number of buffer slots can be located between the lifts and the respective levels. These systems are already treated in various scientific papers. In this paper, the calculation of the throughput of a shuttle system and, more particularly, the calculation of the energy consumption for the handling of a tote in such a system is presented. The results of these calculation methods are shown.

Keywords: shuttle-system, storage/retrieval unit load systems, performance, analytical calculation, energy consumption

\section{INTRODUCTION AND PROBLEM DEFINITION}

Due to the development of the economy to demandoriented delivery and storage of consumables and products, the requirements for the storage technology are becoming higher and higher. In order to meet these requirements, shuttle systems are increasingly installed. They are flexible and achieve highest performances. The focus of this paper is not only on the calculation of the throughput, but on the calculation of the energy consumption for storage and retrieval.

A number of research papers have been published in the past to investigate these systems $[3,4,5]$.

In detail, the following research questions will be treated:

$>$ Which throughput can be achieved by shuttle systems?

$>$ What is the energy consumption for one double cycle?

\section{DESCRIPTION OF THE SHUTTLE SYSTEM}

The shuttle system treated here is a system with container lifts. This means that the shuttles can not leave the individual levels and the lifts transport only the totes. So there must be a shuttle in each level of the system. Between lifts and shuttles there is a buffer installed. See Figure 1.

\section{ANALYTICAL CALCULATION OF THE THROUGHPUT}

In order to calculate the throughput of an entire shuttle system the utilization rate of a single level must be determined first. This is done with the following equation:

Received: January 2018, Accepted: March 2018

Correspondence to: Prof. Georg Kartnig, Vienna

University of Technology, Faculty of Mechanical and

Industrial Engineering, Vienna, Austira

E-mail: georg.kartnig@tuwien.ac.at

doi:10.5937/fmet1803424E

(C) Faculty of Mechanical Engineering, Belgrade. All rights reserved

$$
\rho=\frac{\lambda}{\mu}=\frac{t_{o}}{t_{a}}
$$

It includes the relationship between the interarrivaltime of the lifts $t_{a}$ and the operationg time of the shuttles $\mathrm{t}_{\mathrm{o}}$.

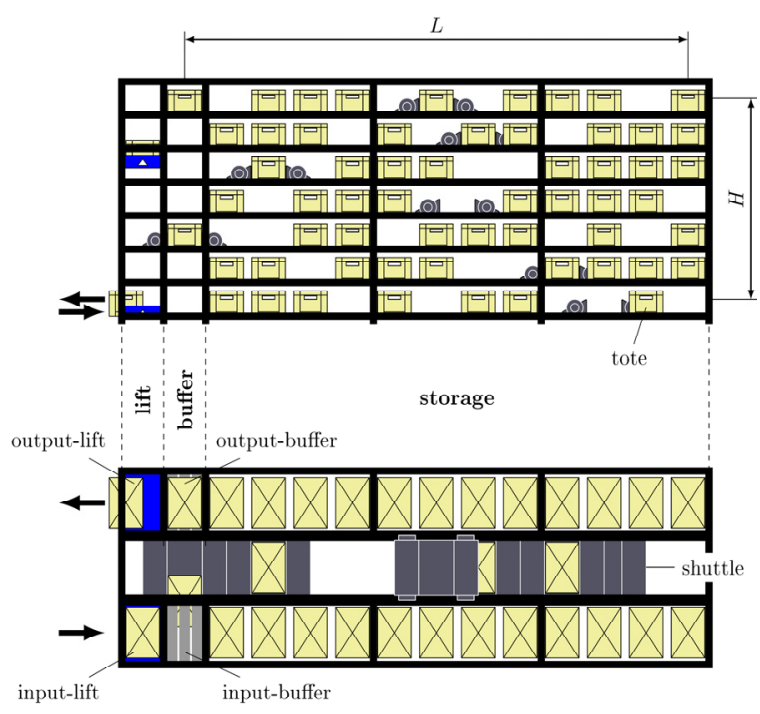

Figure 1. Shuttle-System

The interarrival time is the mean cycle time of the lifts converted to the individual levels. This conversion is done by the multiplication of the cycle time by the number of levels in the rack:

$$
t_{a}=t_{\text {lift }} \cdot n_{\text {level }}
$$
[1]:

The mean cycle time of the lifts is defined as follows

$$
t_{\text {lift }}=\frac{H}{v_{\text {lift }}}+2 \frac{v_{\text {lift }}}{a_{\text {lift }}}+t_{\text {load/unload_lift }}
$$

The second part in determining the utilization rate of one level is the mean operating time of the shuttles. This is calculated as follows [1]. 
$t_{o}=t_{\text {shuttle }}$

$t_{\text {shuttle }}=\frac{4}{3} \frac{L}{v_{\text {shuttle }}}+3 \frac{v_{\text {shuttle }}}{a_{\text {shuttle }}}+t_{\text {load/unload_shuttle }}$

In order to calculate the throughput a queuing system $\mathrm{M}|\mathrm{G}| 1 \mid \mathrm{K}$ is used. The throughput of one level is given by the following equation [2]:

$$
\vartheta_{\text {level }}=\frac{1}{t_{a}}\left(1-p_{K}\right)=\frac{1}{t_{b}}\left(1-p_{0}\right)
$$

The result of this queuing must be converted with the following relationship, to get the result for the whole system.

$$
\vartheta_{\text {system }}=\vartheta_{\text {level }} \cdot n_{\text {level }}
$$

Equation (6) shows two methods for determining the throughput. On the one hand by the interarrivaltime and the blocking probability, on the other hand, via the operating time and the vacancy probability.

The basic equation to calculate the blocking probability is [2]:

$$
p_{K}=\frac{\rho^{\left(\frac{\sqrt{\rho} \cdot s_{S}^{2}-\sqrt{\rho}+2 K}{2+\sqrt{\rho} \cdot s_{S}^{2}-\sqrt{\rho}}\right)} \cdot(\rho-1)}{\rho^{\left(2 \frac{\sqrt{\rho} \cdot s_{S}^{2}-\sqrt{\rho}+K+1}{2+\sqrt{\rho} \cdot s_{S}^{2}-\sqrt{\rho}}\right)_{-1}}}
$$

The vacancy probability is quite similar [3]:

$$
p_{0}=\frac{(\rho-1)}{\rho^{\left(2 \frac{\sqrt{\rho} \cdot s_{S}^{2}-\sqrt{\rho}+K+1}{2+\sqrt{\rho} \cdot s_{S}^{2}-\sqrt{\rho}}\right)_{-1}}}
$$

These two equations contain the utilization rate of the individual levels, the variance of the operating times of the shuttles and the capacity of the considered system. The capacity $\mathrm{K}$ of the queuing system can be defined as follows:

$$
K=n_{\text {buffer }}+n_{\text {capShuttle }}
$$

This means that the capacity of the considered waiting system is always the number of input buffer slots in one level $\left(\mathrm{n}_{\text {buffer }}=1\right)$ plus the capacity of the shuttle $\left(\mathrm{n}_{\text {capshuttle }}=1\right)$. In this case, the capacity of the shuttle itself is always provided with one tote.

The variance of the operating times by the shuttle results from the probability distribution of the operating times. These operating times are subjected to a triangular distribution [2]. The variance can therefore be calculated using the following equation.

Table 1. System parameters

\begin{tabular}{|l|c|c|}
\hline & lift & shuttle \\
\hline velocity & $5 \mathrm{~m} / \mathrm{s}$ & $2 \mathrm{~m} / \mathrm{s}$ \\
\hline acceleration & $7 \mathrm{~m} / \mathrm{s}^{2}$ & $2 \mathrm{~m} / \mathrm{s}^{2}$ \\
\hline load-/unload time & $2.8 \mathrm{~s}$ & $4.0 \mathrm{~s}$ \\
\hline vertical pitch & \multicolumn{2}{|c|}{$\mathrm{p}_{\mathrm{v}}=0.4 \mathrm{~m}$} \\
\hline horizontal pitch & \multicolumn{2}{|c|}{$\mathrm{p}_{\mathrm{h}}=0.5 \mathrm{~m}$} \\
\hline
\end{tabular}

Based on the data in Table 1 the throughput results are shown in Figure 2 for single deep racks with a length of $100 \mathrm{~m}$. The result could be confirmed by simulation with SIMIO.

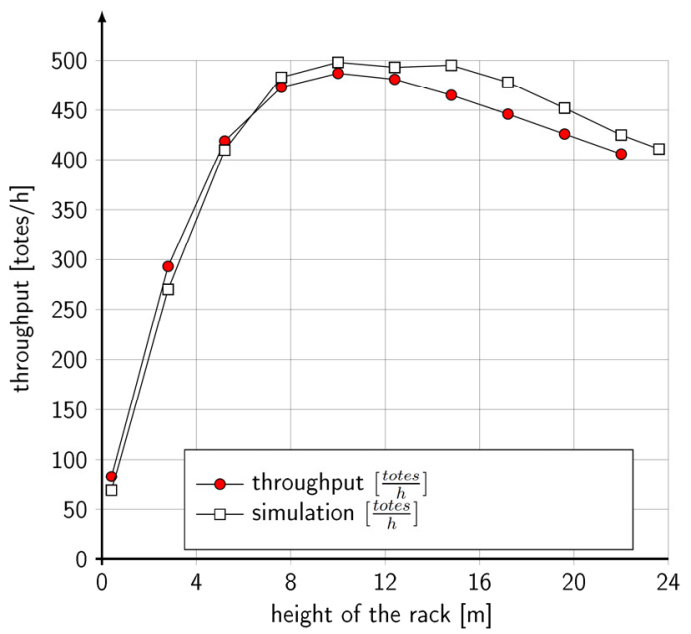

Figure 2. Throughput of a shuttle-system

\section{ANALYTICAL CALCULATION OF THE ENERGY CONSUMPTION}

The calculation of the energy consumption of a shuttle system consists of the energy consumption for the acceleration or decceleration, the energy for a ride with constant speed, the energy for lifting movement and the consumptions for the storage and retrieval. These individual consumptions are listed below. Also the limits of validity for the given equations are shown. This calculation method has been introduced to compare different systems and configurations.

\subsection{Energy consumption of the whole shuttle- system}

The energy consumption of the whole shuttle system attributed to one double cycle of a tote is as follows. In addition to the energy consumption of the lifts and the shuttle, the standby consumptions of all lifts and shuttles including the energy consumption of the control of the whole shuttle system, are divided by the handling performance.

\subsection{Energy consumption for the vehicles}

In this part, the equations are shown for the two main parts of a shuttle system, the lift and the shuttle. These two equations relate to one storage and retrieval process including the energy consumption of the vehicles when riding without any load.

$$
s_{s}=\frac{\sqrt{\frac{\left(2 \frac{L}{v_{\text {shuttle }}}\right)^{2}}{18}}}{t_{\text {shuttle }}}
$$

$E_{\text {system }}=E_{\text {lift }}+E_{\text {shuttle }}$

$+\frac{E_{\text {lifts } \tan d b y} n_{\text {lift }}+E_{\text {shuttles } \tan d b y} n_{\text {shuttle }}+E_{\text {control }}}{\vartheta_{\text {system }}}$ 
Lift single cycle

$$
\begin{aligned}
& E_{\text {lift }}= \\
& +E_{A h v u}+E_{R h v u}+E_{\text {liftup }}+E_{D v u} \\
& +\left(E_{A v d}+E_{R v d}+E_{d o w n}+E_{D h v d}\right) \cdot \eta_{\text {reklift }} \\
& +E_{A h v u}+E_{R h v u}+E_{\text {liftup }}+E_{D v u} \\
& +\left(E_{A v d}+E_{R v d}+E_{\text {down }}+E_{D h v d}\right) \cdot \eta_{\text {reklift }} \\
& +2 \cdot E_{\text {load/unload_lift }}
\end{aligned}
$$

Shuttle double cycle

$$
\begin{aligned}
& E_{\text {Shuttle }}= \\
& +E_{\text {Ahvu }}+E_{R h v u}+E_{D h v d} \cdot \eta_{\text {reklift }} \\
& +E_{A h v u}+E_{R h v u}+E_{D h v d} \cdot \eta_{\text {reklift }} \\
& +E_{\text {Ahvu }}+E_{R h v u}+E_{D h v d} \cdot \eta_{\text {reklift }} \\
& +2 \cdot E_{\text {load/unload_shuttle }}
\end{aligned}
$$

\subsection{Energy consumption for acceleration an deceleration}

The special thing about energy consumption for accelerating and decceleration is that there is also negative consumption. This happens for example when the lift accelerates downwards and the acceleration is less than the gravity. There are four different equations to calculate the energy consumption for acceleration depending on the riding direction.

First the acceleration in horizontal directon or vertical direction upwards is described.

$$
E_{\text {Ahvu }}=+\left(m_{\text {tote }}+m_{v e h}+m_{\text {redveh }}\right) \frac{v_{v e h}^{2}}{2} \frac{1}{\eta_{v e h}}
$$

Next the acceleration in the vertical direction downwards is shown.

$$
E_{\text {Avd }}=+\left(m_{\text {tote }}+m_{v e h}+m_{\text {redveh }}\right) \frac{v_{v e h}^{2}}{2} \eta_{v e h}
$$

The following equation relates to the decceleration process downwards or in horizontal direction.

$$
E_{\text {Dhvd }}=-\left(m_{\text {tote }}+m_{v e h}+m_{\text {redveh }}\right) \frac{v_{v e h}^{2}}{2} \eta_{v e h}
$$

The fourth and last equation includes the decceleration process in vertical direction upwards.

$$
E_{D v u}=-\left(m_{\text {tote }}+m_{v e h}+m_{\text {redveh }}\right) \frac{v_{v e h}^{2}}{2} \frac{1}{\eta_{v e h}}
$$

For vertical transportation the following limit is relevant:

$$
\begin{aligned}
& \left(m_{\text {tote }}+m_{\text {veh }}+m_{\text {redveh }}\right) \cdot a_{\text {veh }} \leq \\
& \left(m_{\text {tote }}+m_{\text {veh }}\right) \cdot g \cdot \mu_{\text {veh }}+\left(m_{\text {tote }}+m_{\text {veh }}\right) \cdot g
\end{aligned}
$$

This means that the mass of the vehicle, including the tote and the reduced rotating mass, multiplied by the acceleration has to be less than the mass of the vehicle including the tote multiplied by the acceleration due to gravity and increased by the coefficient of friction.

\subsection{Energy consumption for constant speed ride}

The energy consumption of a ride with constant speed is the energy consumption required to overcome friction work.

Equation 20 defines this energy consumption for a ride in horizontal direction or a ride vertically upwards. In this case, energy always must be put into the system, so the efficiency of the vehicle is in the denominator.

$$
E_{R h v u}=\left(m_{\text {tote }}+m_{v e h}\right) \cdot g \cdot \mu_{v e h} \cdot L \cdot \frac{1}{\eta_{v e h}}
$$

Equation 21 defines this energy consumption for a ride vertically downwards. Here the efficiency is in the numerator, because this energy consumption reduces the output from the system.

$$
E_{R v d}=-\left(m_{\text {tote }}+m_{v e h}\right) \cdot g \cdot \mu_{v e h} \cdot L \cdot \eta_{v e h}
$$

The limit for the validity of the second part of the energy consumption equation is that the friction force is less than the weight force of the vehicle including the tote.

$$
\left(m_{\text {tote }}+m_{v e h}\right) \cdot \mu_{v e h} \cdot g \leq\left(m_{\text {tote }}+m_{v e h}\right) \cdot g
$$

\subsection{Energy consumption for lifting and ride down- wards}

For the lifting movement the potential energy must be added to the system and therefore the efficiency of the vehicle is in the denominator.

$$
E_{\text {liftup }}=\left(m_{\text {tote }}+m_{\text {veh }}\right) \cdot g \cdot H \cdot \frac{1}{\eta_{\text {veh }}}
$$

When riding downwards, the potential energy is released from the system, so the efficiency is here in the numerator.

$$
E_{\text {down }}=-\left(m_{\text {tote }}+m_{v e h}\right) \cdot g \cdot H \cdot \eta_{\text {veh }}
$$

\section{RESULTS FROM THE CALCULATION OF THE ENERGY CONSUMPTION}

Based on the data in Table 1 and Table 2 the energy consumption and the throughput results are shown in Figure 3 for single deep racks with a length of $100 \mathrm{~m}$.

Table 2. System parameters

\begin{tabular}{|l|c|c|}
\hline & lift & shuttle \\
\hline mass & $5 \mathrm{~m} / \mathrm{s}$ & $2 \mathrm{~m} / \mathrm{s}$ \\
\hline red. rot. mass & $7 \mathrm{~m} / \mathrm{s}^{2}$ & $2 \mathrm{~m} / \mathrm{s}^{2}$ \\
\hline coefficient of friction & 0.1 & 0.1 \\
\hline efficiency & 0.7 & 0.75 \\
\hline recuperation efficiency & 0.5 & 0,5 \\
\hline load/unload energy & $300 \mathrm{~J}$ & $800 \mathrm{~J}$ \\
\hline standby energy & $0.010 \mathrm{kWh} / \mathrm{h}$ & $0.010 \mathrm{kWh} / \mathrm{h}$ \\
\hline control energy & \multicolumn{2}{|c|}{$0.5 \mathrm{kWh} / \mathrm{h}$} \\
\hline mass of the tote & \multicolumn{2}{|c|}{$25 \mathrm{~kg}$} \\
\hline
\end{tabular}




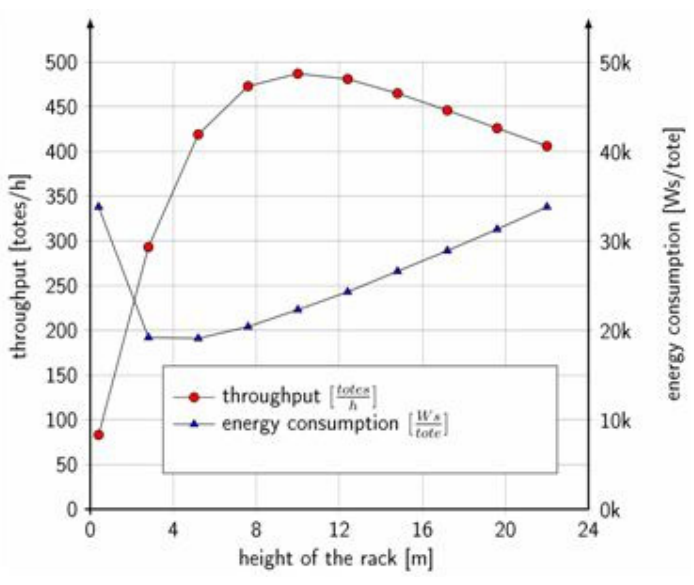

Figure 3. Energy consumption and throughput of a shuttlesystem

On the right side of the figure the influence of the lift is dominating and so the energy comsumption increases with increasing height of the rack. On the left side the constant parts of the energy comsumption are dominating and so the curve is decreasing with increasing throughput. The two curves are nearly mirrored. This is because, in one calculation, the lengths of the rack is in the denominator and in the other it is in the numerator. There is a difference in the position of the extremes (the minimum energy consumption or the maximum handling capacity). This difference results from the waiting time in the calculation of the troughput.

\section{CONCLUSION}

With the present calculation methods the throughput and the energy consumption of shuttle systems can be calculated. These two calculation methods are shown here for single deep racks. They are also available for multi deep racks. In future these methods shall be used to optimize the geomety of the racks.

\section{REFERENCES}

[1] Eder, M.; Kartnig, G.: Throughput Analysis of $S / R$ Shuttle Systems and Ideal Geometry for High Performance. In: FME Transactions 44 (2016), S.174-179. DOI 10.5937/fmet1602174

[2] Eder, M.; Kartnig, G.: Throughput optimization of shuttle systems using an analytical calculation model. In: Logistics Journal: Proceedings 2016, DOI 10.2195/lj_Proc_eder_de_201610_01

[3] Lerher, T.: Throughput and energy Related Performance Calculations for Shuttle Based Storage and Retrieval Systems. In: Nova Science Publishers 2016

[4] Lerher, T.; Edl, M.; Rosi, B.: Energy efficiency model fo the mino-load automated storage and retrieval systems. In: The International Journal of Advanced Manufacturing Technology 70 (2014), Nr. 1-4, S.97-115

[5] Tappia, E.; Marchet, G.; Melacinci, M.; Perotti, S.: Incorporation the environmental dimension in the assessment of automated warehouses.. In: Production Planning \& Control 26 (2015), Nr. 10, S824-838

\section{NOMENCLATURE}

$$
\begin{aligned}
& a_{\text {lift }} \\
& a_{\text {shuttle }} \\
& a_{v e h} \\
& E_{\text {Ahvu }} \\
& E_{\text {Avd }} \\
& E_{\text {control }}
\end{aligned}
$$$$
E_{\text {Dhvd }}
$$$$
E_{\text {down }}
$$$$
E_{D v u}
$$$$
E_{\text {lift }}
$$$$
E_{\text {lifts } \tan d b y}
$$$$
E_{\text {liftup }}
$$$$
E_{\text {load/unload_lift }}
$$$$
E_{\text {load/unload shuttle }}
$$$$
E_{\text {Rhvu }}
$$$$
E_{R v d}
$$$$
E_{\text {shuttle }}
$$

$E_{\text {shuttles } \tan d b y}$

$$
E_{\text {system }}
$$

$g$

$H$

K

$L$

$m_{\text {lift }}$

$m_{\text {redlift }}$

$m_{\text {redshuttle }}$

$m_{\text {redveh }}$

$m_{\text {tote }}$

$m_{\text {shuttle }}$

$m_{v e h}$ acceleration of the lift

acceleration of the shuttle

acceleration of the vehicle

Energy consumption for acceleration in horizontal and vertical direction upwards Energy consumption for acceleration in vertical direction downwards Energy consumption of the control station of the shuttle system

Energy consumption for deceleration in horizontal and vertical direction downwards Energy consumption for lifting a tote downwards Energy consumption for deceleration in vertical direction upwards

Energy consumption for one cycle of the lift

Energy consumption of the lift while waiting

Energy consumption for lifting a tote upwards

Energy consumption for loading and unloading the lift

Energy consumption for loading and unloading the shuttle

Energy consumption for constant ride in horizontal and vertical direction upwards

Energy consumption for constant ride in vertical direction upwards Energy consumption for one cycle of the shuttle

Energy consumption of the shuttle while waiting Energy consumption for one handling cycle of the whole shuttle system gravitational acceleration Height of the rack capacity of the queuing system Length of the rack

Mass of the lift reduced rotating masses of the lift reduced rotating masses of the shuttle reduced rotating masses of the vehicle

Mass of the tote

Mass of the shuttle mass of the vehicle 


$\begin{array}{ll}n_{\text {buffer }} & \begin{array}{l}\text { number of buffer slots between } \\ \text { lifts and shuttle in one storage } \\ \text { level }\end{array} \\ n_{\text {capshuttle }} & \begin{array}{l}\text { transporting capacity of a shuttle } \\ n_{\text {level }}\end{array} \\ n_{\text {lift }} & \text { number of storage levels } \\ n_{\text {shuttle }} & \text { number of lifts in the system } \\ p_{0} & \text { number of shuttles in the system } \\ p_{k} & \begin{array}{l}\text { Unconditional probability that } \\ \text { there is no tote in the service }\end{array} \\ t_{\text {load/unload_lift }} & \text { channel } \\ t_{\text {load/unload_shuttle }} & \text { blocking probability } \\ t_{a} & \begin{array}{l}\text { loading/unloading time of the lifts } \\ \text { shuttles }\end{array} \\ t_{o} & \text { interarrival time } \\ t_{\text {lift }} & \text { operating time } \\ t_{\text {shuttle }} & \text { cycle time of the lifts } \\ s_{s} & \text { cycle time of the shuttles } \\ v_{\text {lift }} & \text { Variance of the operation time } \\ v_{\text {shuttle }} & \text { velocity of the lift } \\ v_{\text {veh }} & \text { velocity of the shuttle }\end{array}$

\section{Greek symbols}

$\vartheta_{\text {level }} \quad$ throughput of a storage level

$\vartheta_{\text {system }}$ throughput of the whole shuttle system

$\rho \quad$ utilization rate $\lambda \quad$ arrival rate

$\mu \quad$ service rate

$\mu_{\text {lift }} \quad$ friction coefficient of the lift

$\mu_{\text {shuttle }} \quad$ friction coefficient of the shuttle

$\mu_{v e h} \quad$ friction coefficient of the vehicle

$\eta_{\text {lift }} \quad$ efficiency of the lift

$\eta_{\text {shuttle }} \quad$ efficiency of the shuttle

$\eta_{\text {reklift }} \quad$ efficiency of recuperation of the lift

$\eta_{\text {rekshuttle }}$ efficiency of recuperation of the shuttle

$\eta_{v e h} \quad$ efficiency of the vehicle

\section{МЕТОД РАЧУНСКОГ ОДРЕБИВАЫА ПРОТОКА И ПОТРОШЫЕ ЕНЕРГИЈЕ КОД ШАТЛ СИСТЕМА СКЛАДИШТЕЫА}

\section{М. Едер, Г. Картниг}

Шатл системи су аутоматски системи великих перформанси за ускладиштење складишних јединица. Сваки ниво складишта опслужује један шатл. С предње стране регала налази се лифт за ускладиштење и искладиштење. Различит број бафера се може налазити између лифтова и њима одговарајућих нивоа. О овим системима се већ расправља у различитим научним радовима.

У овом раду је приказано израчунавање протока код шатл система и, посебно, израчунавање потрошње енергије у функционисању целокупног шатл система. Приказани су резултати примене рачунске методе. 